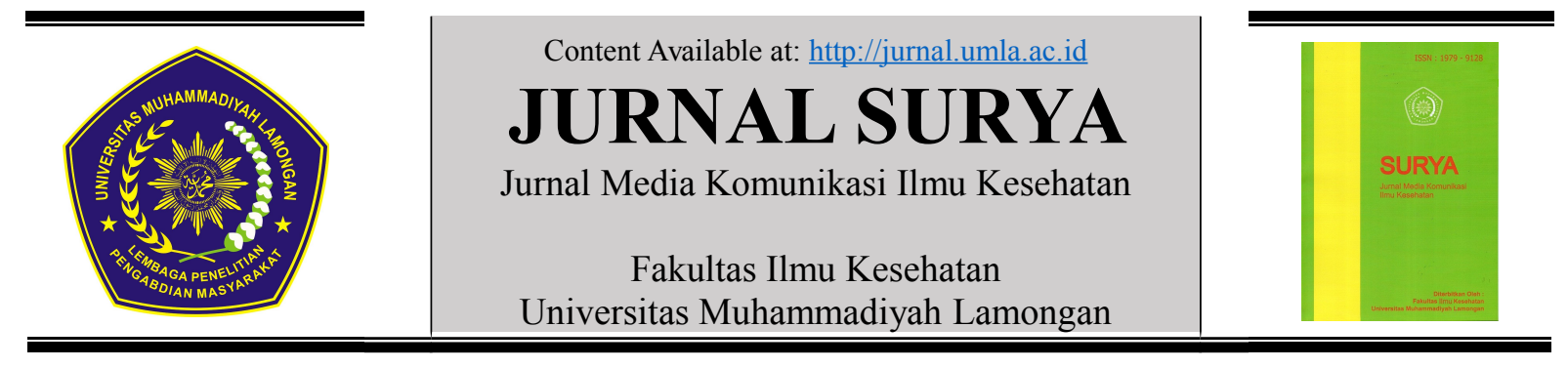

\title{
Penggunaan Electronic Medication Management (EMM) dalam Menurunkan Kejadian Medication Error di Keperawatan
}

Siti Indriani ${ }^{1}$, Bhekti Setya Ningrum ${ }^{2}$, Rr. Tutik Sri Hariyati ${ }^{3}$

Mahasiswa Magister Keperawatan Kepemimpinan Dan Manajemen Pelayanan Keperawatan Universitas Indonesia

ARTIKEL INFO

Article History:

SM at 02-12-2019

$R V$ at $02-12-2019$

$P B$ at 24-12-2019

\section{Kata Kunci:}

Manajemen Obat Elektronik

Kesalahan Pemberian Obat

Korespondensi Penulis: siti.indriani75@yahoo.com

\begin{abstract}
ABSTRAK
Background: Mengurangi kejadian medication error akan secara signifikan meningkatkan keselamatan pasien dan kualitas penggunaan obat-obatan. Sistem tradisional membuat staf menghabiskan waktu mencari melalui catatan berbasis kertas ketika menentukan obat apa yang harus dibayar pasien sepanjang proses pengobatan yang diberikan. Sistem EMM mendukung peningkatan kualitas, keamanan, dan efektivitas manajemen obat di rumah sakit. Ini termasuk memberikan dukungan bagi dokter, perawat dan apoteker untuk meresepkan, memesan, memeriksa, merekonsiliasi, mengeluarkan dan mencatat administrasi obat secara digital. EMM mencakup seluruh siklus pengobatan di rumah sakit termasuk peresepan oleh dokter, meninjau dan mengeluarkan pesanan obat oleh apoteker, dan administrasi obat oleh perawat. Penggunaan EMM dapat memberikan manfaat yaitu meningkatkan kualitas asuhan keperawatan yang berorientasi kepada pasien, kualitas layanan klinis dan pemanfaatan teknologi informasi.
\end{abstract}

Objectives: Perawat diharapkan mampu mengikuti perkembangan di bidang teknologi informasi khususnya dalam penerapannya dibidang asuhan keperawatan. Artikel ini membahas tentang literature review terkait penggunaan EMM dalam menurunkan kejadian medication error.

Design: Kajian literatur ini menggunakan metode PRISMA Results: Penelitian dengan kajian literature ini menunjukkan bahwa penggunaan EMM dapat menurunkan kejadian medication error

Conclusions: Penggunaan implementasi EMM dapat menurunkan kejadian medication error dan meningkatkan efisiensi di rumah sakit, seperti mengurangi waktu proses peresepan pasien, ketepatan mulai persiapan sampai pemberian obat serta memasok obat-obatan. EMM yang direncanakan dan diimplementasikan oleh sumber daya yang baik, akan menghasilkan manfaat yang baik, yaitu dapat menurunkan medication error yang memiliki potensi mempengaruhi keselamatan pasien dan kualitas keperawatan. 
PENDAHULUAN

Rumah Sakit adalah institusi pelayanan kesehatan yang menyelenggarakan pelayanan kesehatan perorangan secara paripurna yang menyediakan pelayanan rawat inap, rawat jalan, dan gawat darurat. Di setiap pelayanan tersebut diperlukan proses pemberian obat kepada pasien, kewajiban rumah sakit melindungi pasien dan masyarakat dari penggunaan obat yang tidak rasional dalam rangka keselamatan pasien (patient safety). (Kemenkes, 2016)

Medication error merupakan insiden serius yang dapat menimbulkan kecacatan bahkan kematian pasien. Penelitian di Australia pada tahun 2016 medication error dikarenakan kesalahan peresepan ada 3-37\% dari kesalahan obat, persiapan obat 5-58\%, pemberian obat $72-75 \%$ dan dokumentasi $17-$ $21 \%$, meskipun akurasi estimasi dipengaruhi oleh variabilitas yang besar dalam definisi dan metode pengukuran yang digunakan. Penemuan tersebut juga menemukan 19,2\% pasien rawat inap anak-anak mengalami efek samping obat (Adverse Drug Events/ADE) dan diperkirakan $12,3 \%$ adalah potensi $\mathrm{ADE}$, $7,0 \%$ adalah ADE aktual dan 3,6\% dapat dicegah. (Westbrook et al., 2016)

Angka kejadian medication error di Indonesia tidak terdata dengan jelas, namun dari penelitian di instalasi farmasi Rumah Sakit Bhayangkara Tk.III Manado periode bulan Januari 2019 dari 332 resep pasien rawat jalan Poli Interna, hasil penelitian menunjukkan bahwa terjadi Medication Error pada Fase prescribing meliputi; tidak ada tanggal lahir (usia) $80.12 \%$, tidak ada bentuk sediaan $38.85 \%$, tidak ada konsentrasi/dosis sediaan $27.71 \%$, tidak lengkap penulisan resep obat keras $6.32 \%$, tulisan resep tidak terbaca $3.01 \%$, salah/tidak jelas nama pasien $1.20 \%$, tidak ada jumlah obat $0.30 \%$ dan tidak ada aturan pakai $0.30 \%$. Medication Error yang terjadi pada Fase dispensing meliputi; pemberian obat diluar instruksi $8.13 \%$, obat yang diserahkan kurang $1.81 \%$, dan penulisan etiket yang salah atau tidak lengkap $0.30 \%$ (Tiansi Maalangen, 2019).

Dalam sistem perawatan kesehatan dengan meningkatnya kompleksitas pasien dan distribusi perawatan, standar tinggi perawatan pasien tidak lagi dapat didukung oleh manajemen informasi berbasis kertas tradisional (Vicente Oliveros et al., 2017). Sistem Elektronik Medication Management (EMM) menggabungkan perangkat lunak yang memberi pengguna kemampuan untuk meresepkan, memantau, dan memberikan obat kepada pasien. Sistem ini juga menyediakan kapasitas untuk menggabungkan alat pendukung keputusan seperti peringatan untuk interaksi obat-obat. EMM biasanya diintegrasikan ke dalam sistem informasi klinis rumah sakit (sistem entri pesanan penyedia layanan terkomputerisasi). Sistem ini diharapkan dapat mengurangi kesalahan pengobatan dan ADE secara signifikan sebagai hasil dari peningkatan keterbacaan pesanan obat, dokumentasi yang lengkap dan sesuai hukum, dan melalui alat pendukung keputusan aktif dan pasif yang tertanam di dalamnya (Westbrook et al., 2016).

Di Indonesia, setiap rumah sakit dapat menerapkan berbagai jenis sistem informasi kesehatan. Menurut Bagian 1 dari Peraturan Pemerintah Indonesia Nomor 46 Tahun 2014, sistem informasi kesehatan didefinisikan sebagai "seperangkat struktur yang mencakup data, informasi, indikator, prosedur, alat, teknologi, dan sumber daya manusia yang saling terkait dan dikelola dalam cara terpadu untuk mengarahkan tindakan atau keputusan yang bermanfaat dalam mendukung pembangunan kesehatan. Salah satu jenis Sistem Informasi Kesehatan (HIS) yang telah diadopsi di banyak rumah sakit di Indonesia adalah sistem Electronic Medical Record (EMR) yang mengintegrasikan data kesehatan pasien (Erlirianto, Ali, \& Herdiyanti, 2015).

Tingkat medication error dilaporkan dalam literatur berkisar dari 1,2 hingga 947 per 1.000 hari pasien di Medical ICU (MICU). Satu penelitian observasional, prospektif, di salah satu pusat kesehatan kesalahan dalam MICU dan unit perawatan jantung melaporkan 78\% kesalahan serius terkait dengan pengobatan. Penelitian lainnya telah melaporkan tingkat kesalahan pengobatan antara 4,5 dan 16 kesalahan per 100 resep obat (Liao et al., 2017).

Kelalaian dosis telah dilaporkan terjadi pada 4,2\% hingga 30\% dari dosis yang diaudit. EMMS, diimplementasikan di rawat inap dan rawat jalan, telah dilaporkan dapat meningkatkan keamanan obat yang terkait 
dengan peresepan dan pemberian obat. Penyebab umum kesalahan pengobatan terkait peresepan meliputi kemiripan obat (Look alike sound alike), tulisan tangan tidak terbaca, kesalahan transkripsi, singkatan yang tidak tepat, dan perhitungan dosis yang tidak akurat. Dibandingkan dengan catatan medis kertas, EMMS telah terbukti mengurangi prevalensi jenis medication error (Hunt, Harding, Taylor, \& Curtain, 2018).

Oleh karena itu penulis tertarik untuk membahas lebih lanjut literatur tentang penerapan EMM dalam proses pemberian obat untuk menurunkan kejadian medication error.

Electronic Medication Management adalah sistem peresepan, seperti sistem desktop dokter atau sistem informasi klinis rumah sakit yang memiliki pemesanan elektronik. Alasan utama untuk mengimplementasikan EMM adalah untuk meningkatkan keamanan obat. Menerapkan sistem EMM memungkinkan manajemen resep pasien yang aman. Pada 2009, Reformasi Kesehatan dan Rumah Sakit Nasional Australia (Care, 2019) menyatakan bahwa;

Sekitar 2-3\% dari kunjungan di rumah sakit terkait obat, sekitar $10 \%$ pasien datang ke praktik umum mengalami efek samping obat, tingkat kesalahan pengobatan sangat tinggi pada pasien lanjut usia, dan selama transfer perawatan antara rumah sakit dan komunitas, serta diperkirakan 52-88\% kesalahan dalam dokumen transfer.

Penerapan sistem EMM pada titik perawatan akan :

1. Minimalkan bahaya pada pasien

2. Mengurangi duplikasi

3. Mengurangi limbah

4. Meningkatkan efisiensi seluruh sistem.

Penggunaan EMM untuk memesan obat telah disebut sebagai aplikasi informasi yang paling menjanjikan teknologi untuk membantu mengurangi kesalahan pengobatan. Mengotomatiskan proses pemesanan obat menghasilkan pesanan terstandarisasi, terbaca dan lengkap. EMM juga mencegah kesalahan tarif untuk rawat inap rumah sakit diidentifikasi signifikan penurunan kesalahan penulisan yang terkait dengan salah dokumentasi pesanan obat-obatan. Namun, ada risiko konsekuensi yang tidak diinginkan dan muncul kesalahan baru jika implementasi
EMM tidak direncanakan dengan baik, tidak memiliki dukungan keputusan klinis atau sistem tidak terhubung dengan layanan kesehatan lainnya dalam sistem organisasi. Aplikasi yang dirancang dengan buruk dan kegagalan untuk mengnyediakan kebutuhan organisasi akan menimbulkan resiko baru yang tak terduga dalam keselamatan pasien.

Semakin banyak rumah sakit dan layanan kesehatan beralih ke sistem digital sebagai solusi. Sistem EMM mendukung peningkatan kualitas, keamanan, dan efektivitas manajemen obat di rumah sakit. Ini termasuk memberikan dukungan bagi dokter, perawat dan apoteker untuk meresepkan, memesan, memeriksa, merekonsiliasi, mengeluarkan dan mencatat administrasi obat secara digital. EMM mencakup seluruh siklus pengobatan di rumah sakit termasuk meresepkan oleh dokter, meninjau dan mengeluarkan pesanan obat oleh apoteker, dan administrasi obat oleh perawat. EMM dapat berlaku untuk; sistem peresepan, atau sistem informasi klinis rumah sakit yang memiliki pemesanan elektronik, sistem pendukung keputusan, seperti perangkat pesanan berbasis bukti, pengecekan alergi dan interaksi obat, sistem pengeluaran, seperti perangkat lunak farmasi dan sistem pengeluaran otomatis. Memesan dan memasok, seperti Electronic Transfer Prescribtion (ETP) dan solusi inventarisasi.

Menurut WHO, tidak ada konsensus tentang definisi kesalahan pengobatan. Tinjauan literatur sistematis menemukan 26 terminologi berbeda yang digunakan untuk kesalahan pengobatan. Dewan Koordinasi Nasional Amerika Serikat untuk Pelaporan dan Pencegahan Kesalahan Pengobatan mendefinisikan kesalahan pengobatan sebagai:

"Setiap kejadian yang dapat dicegah yang dapat menyebabkan atau mengarah pada penggunaan obat yang tidak tepat atau membahayakan pasien saat obat berada dalam kendali profesional kesehatan, pasien, atau konsumen. Peristiwa semacam itu mungkin terkait dengan praktik profesional, produk kesehatan, prosedur, dan sistem, termasuk peresepan, komunikasi pesanan, pelabelan produk, pengemasan, dan nomenklatur, peracikan, pengeluaran, distribusi, administrasi, pendidikan, 
pemantauan,

penggunaan"(Organization, 2016)

dan

WHO juga menyatakan faktor yang dapat meningkatkan kejadian medication error terkait dengan factor profesional petugas kesehatan, faktor pasien dan faktor sistem komputerisasi, dan factor obat-obatan (Organization, 2016).

\section{METODE}

Tinjauan literatur menggunakan metode PRISMA dalam mendeskripsikan konsep electronic medication management dan medication error.

1. Kriteria eligibilitas

Penulis menggunakan berbagai penelitian baik secara metode kuantitatif dan kualitatif dalam penggunaan EMM dalam menurunkan medication error.

2. Strategi pencarian

Penulis melakukan beberapa proses pencarian untuk mendapatkan artikel dalam rentang waktu 5 tahun dalam Bahasa Inggris dan Indonesia yang relevant terhadap pembahasan penggunaan EMM dalam menurunkan medication error.

3. Seleksi

Penulis menggunakan basis data yang berlaku seperti PubMed, EBSCo, Wiley, Science direct, Embase, CINAHL, Cochrane. Lalu dilakukan identifikasi dan analisa artikel penelitian yang relevan.

4. Sintesis hasil

Kajian literatur menggambarkan dan menjelaskan perkembangan EMM dalam menurunkan kejadian medication error.

HASIL

Hasil penelitian ini bertujuan untuk mengevaluasi dampak dari implementasi EMM pada efisiensi pemberian obat dan terjadinya kesalahan pengobatan serta untuk mengidentifikasi prediktor efisiensi pemberian obat.

Dari penelitian prospektif, observasional yang dilakukan sebelum dan sesudah implementasi catatan administrasi obat elektronik pada bulan November 2011. Sebanyak 156 kasus kegiatan administrasi obat (78 catatan administrasi obat dengan kertas dan 78 elektronik) melibatkan 38 perawat diamati pada titik perawatan. Waktu pemberian obat rata-rata sebenarnya meningkat dari 11,3 menjadi 14,4 menit catatan pemberian obat pasca elektronik $(\mathrm{P}=$ 0,039). Dalam analisis multivariat, catatan pemberian obat elektronik bukan merupakan prediktor waktu pemberian obat, tetapi gangguan / gangguan selama proses pemberian obat adalah prediktor yang signifikan. Kesalahan pengobatan rata-rata di seluruh rumah sakit secara signifikan menurun dari 11,0 menjadi 5,3 peristiwa per bulan catatan administrasi obat pascaelektronik $(\mathrm{P}=0,034)$. Meskipun tidak ada peningkatan dalam efisiensi administrasi pengobatan yang diamati, catatan administrasi pengobatan elektronik meningkatkan kualitas perawatan dengan penurunan yang signifikan dalam kesalahan pengobatan (MCCOMAS, 2016).

Selama periode pra dan pasca $\mathrm{CPOE}$ (dua hari untuk masing-masing periode), 111 dan 86 pasien diamati, masing-masing, dengan 1.593 dan 1.388 obat resep yang sesuai. Penggunaan resep elektronik menyebabkan penurunan signifikan 92\% dalam kesalahan resep (479/1593 obat yang diresepkan $(30,1 \%)$ vs 33/1388 (2,4\%), p $<0,0001)$ dan ke $17,5 \%$ penurunan signifikan dalam kesalahan administrasi (209 / 1222 peluang $(17,1 \%)$ vs 200/1413 (14,2\%), p $<0,05)$. Tidak ada perbedaan signifikan yang ditemukan sehubungan dengan kesalahan persiapan (430/1219 peluang $(35,3 \%)$ vs 449/1407 (31,9\%), p =0,07) (G D Schiff, 2015).

Tingkat potensi Adverse Drug Events (ADE) setelah implementasi EMM turun signifikan dari 0,17 per penerimaan menjadi 0,05 ; turun $71 \%$. Biaya implementasi, pemeliharaan, dan biaya EMM tahunan untuk bangsal jantung adalah A\$ 61.741 (US \$ 55.296). Estimasi pengurangan ADE pasca EMM adalah sekitar 80 ADE aktual per tahun. Pengurangan biaya yang terkait dengan ADE ini lebih dari cukup untuk mengimbangi biaya EMM. Perkiraan penghematan yang dihasilkan dari implementasi EMM adalah A\$ 63-66 (US \$ 56-59) per penerimaan (A \$ 97 740- \$102.000 per tahun untuk bangsal ini). Analisis sensitivitas menunjukkan hasil yang kuat antara efektivitas EMM dan biaya ADE aktual bervariasi secara substansial (G D Schiff, 2015). 
Penelitian ini secara kajian literatur menyajikan data bahwa dengan menggunakan EMM maka dapat menurunkan kejadian kesalahan pemberian obat.

\section{PEMBAHASAN}

Pada penelitian ini didapatkan suatu hubungan yang positif antara EMM dengan menurunnya angka kejadian medication error. Data yang disajikan pada penelitian McComas (2016) sebanyak 156 kasus Waktu pemberian obat rata-rata sebenarnya meningkat dari 11,3 menjadi 14,4 menit dengan dokumentasi pemberian obat secara elektronik $(\mathrm{P}=0,039)$. Dalam analisis multivariat, dokumentasi pemberian obat elektronik bukan merupakan prediktor waktu pemberian obat, tetapi gangguan- gangguan selama proses pemberian obat adalah prediktor yang signifikan. Kesalahan pengobatan rata-rata di seluruh rumah sakit secara signifikan menurun dari 11,0 menjadi 5,3 kejadian per bulan catatan administrasi obat pasca-elektronik $(\mathrm{P}=0,034)$. Penelitian ini sejalan dengan pernyataan bahwa EMM dapat menurunkan angka kejadian medication error dan efisiensi waktu (Care, 2019).

Pembahasan penelitian GD Schift (2015) yaitu membandingkan dampak penggunaan dokumentasi pemberian obat dengan kertas dibandingkan EMM dihasilkan penurunan signifikan $92 \%$ dalam kesalahan resep (479/1593 obat yang diresepkan $(30,1 \%)$ vs $33 / 1388(2,4 \%)$, p <0,0001) dan ke $17,5 \%$ penurunan signifikan dalam kesalahan administrasi $(209 / 1222$ peluang $(17,1 \%)$ vs $200 / 1413(14,2 \%)$, p $<0,05)$. Tidak ada perbedaan signifikan yang ditemukan sehubungan dengan kesalahan persiapan $(430 / 1219$ peluang $(35,3 \%)$ vs 449/1407 (31,9\%), $\mathrm{p}=0,07)$. Hal ini membuktikan hasil yang signifikan antara penggunaan dokumentasi dengan kertas dan EMM (Care, 2019)

Pada penelitian kedua dari GD Schiff (2015) menghasilkan penghematan yang dihasilkan dari implementasi EMM adalah A\$ 63-66 (US \$ 56-59) per penerimaan (A \$ 97 740- \$ 102.000 per tahun untuk bangsal jantung. Analisis sensitivitas menunjukkan hasil yang kuat antara efektivitas EMM dan biaya ADE. Hal ini sesuai dengan pernyataan EMM dapat bermakna dalam efisiensi biaya, karena bias menekan penggunaan kertas dan biaya yang dikeluarkan akibat medication error (Care, 2019).

\section{KESIMPULAN}

\section{Implementasi EMM dapat} meningkatkan efisiensi di seluruh rumah sakit dalam proses manajemen pengobatan, seperti mengurangi waktu yang dibutuhkan untuk menemukan resep obat-obatan, pemberian dan dokumentasi obat, serta untuk memasok obat-obatan. EMM adalah area kompleks yang melibatkan banyak area fungsional dalam fasilitas kesehatan, dan memiliki sistem elektronik sendiri, dan tidak menjamin praktik yang baik, atau bahwa semua manfaat yang diharapkan akan tercapai. Sistem EMM dapat mengurangi kesalahan pengobatan, tetapi juga memiliki potensi untuk mempengaruhi keselamatan dan kualitas perawatan jika sistem dirancang dan diimplementasikan dengan buruk, dan kekurangan sumber daya. Risiko ini disorot dalam sejumlah penelitian yang menunjukkan peningkatan kesalahan pengobatan setelah implementasi sistem EMM yang tidak direncanakan dengan baik. Risiko ini harus diminimalkan dengan mempersiapkan, mempelajari dan mengevaluasi implementasi EMM yang sesuai dengan kebutuhan organisasi.

\section{DAFTAR PUSTAKA}

Care, A. C. o. S. a. Q. i. H. (2019). Electronic Medication Management Systems A guide to safe implementation. In.

Erlirianto, L. M., Ali, A. H. N., \& Herdiyanti, A. J. P. C. S. (2015). The Implementation of the Human, Organization, and Technology-Fit (HOT-Fit) Framework to Evaluate the Electronic Medical Record (EMR) System in a Hospital. 72, 580587.

G D Schiff, 2 M G Amato,1,3 T Eguale,1,2,4 J J Boehne,1 AWright,1,2 R Koppel,5 A H Rashidee,6 R B Elson,7 D L Whitney,8 T-T Thach,1 D W Bates,1,2,9 A C Seger1,3. (2015). Computerised physician order entry- 
related medication errors: analysis of reported errors and vulnerability testing of current systems.

Hunt, K. V., Harding, A. M., Taylor, S. E., \& Curtain, C. (2018). Evaluation of medication dose omissions amongst inpatients in a hospital using an electronic Medication Management System. Journal of Evaluation in Clinical Practice, 24(4), 688-694. doi:10.1111/jep.12944

Peraturan Menteri Kesehatan Republik Indonesia Nomor 72 Tahun 2016 Tentang Standar Pelayanan Kefarmasian Di Rumah Sakit, (2016).

Liao, T. V., Rabinovich, M., Abraham, P., Perez, S., DiPlotti, C., Han, J., . . . Honig, E. (2017). Evaluation of medication errors with implementation of electronic health record technology in the medical intensive care unit. Open Access Journal of Clinical Trials, 9, 31-40. doi:10.2147/OAJCT.S131211

MCCOMAS, J. M., RN, CNS; RIINGEN, MICHELLE DNP, RN, CNS-BC; CHAE KIM, SON PhD, RN. (2016). Impact of an Electronic Medication Administration Record on Medication Administration Efficiency and Errors. Impact of an Electronic Medication Administration Record on Medication Administration Efficiency and Errors.

Organization, W. H. (2016). Medication errors.

Tiansi Maalangen, G. C., Weny Wiyono (2019). Identifikasi Medication Error Pada Resep Pasien Poli Interna Di Instalasi Farmasi Rumah Sakit Bhayangkara Tk. III Manado.

Vicente Oliveros, N., Gramage Caro, T., Pérez Menendez-Conde, C., Álvarez-Díaz, A. M., Martín-Aragón Álvarez, S., Bermejo Vicedo, T., \& Delgado Silveira, E. (2017). Effect of an electronic medication administration record application on patient safety.
Journal of Evaluation in Clinical Practice, 23(4), 888-894. doi:10.1111/jep.12753

Westbrook, J. I., Li, L., Raban, M. Z., Baysari, M. T., Mumford, V. A.-O., Prgomet, M., . . . Kennedy, P. (2016). Stepped-wedge cluster randomised controlled trial to assess the effectiveness of an electronic medication management system to reduce medication errors, adverse drug events and average length of stay at two paediatric hospitals: a study protocol. (2044-6055 (Electronic)). 